ENCYCLOPEDDIE Encyclopédie berbère

BERBERE

32 | 2010

32 | Mgild - Mzab

\title{
Muctuniana (Manus)
}

Cf. Moukhthousii

\section{OpenEdition}

Journals

Édition électronique

URL : https://journals.openedition.org/encyclopedieberbere/644

DOI : 10.4000/encyclopedieberbere.644

ISSN : 2262-7197

Éditeur

Peeters Publishers

Édition imprimée

Date de publication : 31 décembre 2010

Pagination : 5100

ISBN : 978-90-429-2369-0

ISSN : 1015-7344

\section{Référence électronique}

«Muctuniana (Manus)», Encyclopédie berbère [En ligne], 32 | 2010, document M00, mis en ligne le 31

décembre 2015, consulté le 17 février 2022. URL : http://journals.openedition.org/

encyclopedieberbere/644; DOI : https://doi.org/10.4000/encyclopedieberbere.644

Ce document a été généré automatiquement le 17 février 2022.

(c) Tous droits réservés 


\title{
Muctuniana (Manus)
}

\author{
Cf. Moukhthousii
}

Cf. Moukhthousii 